\title{
Degradation of the pharmaceuticals nimesulide and ibuprofen using photo-Fenton process: toxicity studies, kinetic modeling and use of artificial neural networks
}

\author{
Degradação dos fármacos nimesulida e ibuprofeno empregando processo foto- \\ Fenton: estudos da toxicidade, modelagem cinética e emprego de redes neurais \\ artificiais
}

Rubens Teles Monteiro, Rayany Magali da Rocha Santana, Ana Maria Ribeiro Bastos da Silva, Alex Leandro Andrade de Lucena, Léa Elias Mendes Carneiro Zaidan, Valdinete Lins da Silva, Daniella

Carla Napoleão

Departamento de Engenharia Química, Universidade Federal de Pernambuco, PE, Brasil

rubens.engenheiroquimico@gmail.com; rayanymagalirocha@gmail.com; amrbsilva@ig.com.br; lucenaalex3@gmail.com; leazaidan@yahoo.com.br; leaq_val@yahoo.com.br; danicarlan@gmail.com

\begin{abstract}
The growth of pollution in aquatic environments increases every day, causing compounds like pharmaceuticas to be detected in surface waters. Thus, tecniques such as advanced oxidation processes (AOP) have been used to degrade this compounds. In this work, the efficiency of AOP in the degradation of nimesulide and ibuprofen pharmaceuticals was evaluated through chromatographic analysis as well as organic matter through the levels of chemical oxygen demand (COD) and total organic carbon (TOC). It was verified that the photo-Fenton process presented the bests results, degrading $89.70 \%$ of nimesulide and $93.35 \%$ of ibuprofen. This same process managed to reduce COD by $91.60 \%$ and mineralize $90.04 \%$ of the TOC. The kinetic study showed a good linear fit $\left(R^{2}=0.993\right)$ for the clustered kinetic model, as well as a good fit to the mathematical model of artificial neural networks (ANNs), with a value of $R^{2}=1.000$ for the MLP4-4-1 BFGS 4567 model. Finally, the toxicity of the solution after treatment was verified against the seeds of Lactuta sativa, Cichorium endivia, Ocimum basilicum and American Hard grain. It was found that the seeds that received the solution before treatment had a lower germination amount than the ones where the post AOP treatment solution was added. Then, the root growth was evaluated, in which a relative toxic effect was observed.
\end{abstract}

Keywords: Ibuprofen; Nimesulide; Photo-Fenton

\section{Resumo}

O crescimento da poluição de ambientes aquáticos tem aumentado todos os dias, fazendo com que compostos como os fármacos sejam verificados em águas superficiais. Desse modo, técnicas como processos oxidativos avançados (POA) tem sido utilizadas. Neste trabalho a eficiência dos POA na degradação dos fármacos nimesulida e ibuprofeno foi avaliada, através de análises cromatográficas, bem como de matéria orgânica através dos níveis de demanda química de oxigênio (DQO) e carbono orgânico total (COT). Verificou-se que o processo foto-Fenton apresentou os melhores resultados degradando 89,70\% do nimesulida e 93,35\% do ibuprofeno. Esse mesmo processo conseguiu reduzir em 91,60\% a DQO e mineralizar $90,04 \%$ do COT. O estudo cinético mostrou bom ajuste linear $\left(R^{2}=0,993\right)$ para o modelo cinético agrupado, além de uma boa adequação ao modelo matemático de redes neurais artificiais (RNA), com um valor de $R^{2}=1,000$ para o modelo MLP4-4-1 BFGS4567. Por fim, verificou-se a toxicidade da solução após tratamento, frente às sementes de Lactuta Sativa, Cichorium endívia, Ocimum basilicum e do grão Americano Hard. Verificou-se que as sementes que receberam a solução antes do tratamento apresentaram uma quantidade menor germinação, do que quando foi adicionada a solução pós-tratamento via POA. Em seguida, avaliou-se o crescimento radicular, no qual foi percebido relativo efeito tóxico.

Palavras-chave: Ibuprofeno; Nimesulida; Photo-Fenton 


\section{INTRODUCTION}

Different organic pollutants have been studied with regard to their persistence in the environment. In water the concenr in even greater, since this resource is more and more scarce when it come to drinking standards. Thus, different treatment processes have been studied, since conventional methods of wastewater treatment (physical-chemical and biological) are not able to promote the degradation of more persistent compounds such as pharmaceuticals (NAPOLEÃO et al, 2015) polycyclic aromatic hydrocarbons (ROCHA et al, 2014), plasticizers, perticides, hormones and phenolic compounds (ZAIDAN et al, 2016).

In order to detect these pollutants in aquatic matrices, and at different levels of concentration, the effectiveness of treatments such as advanced oxidation processes (AOP) has been evaluated (SANTOS-JUANES et al, 2011), as well as the adsorption processes (RAJABI et al, 2016). Different types of AOP have show good results, since they act by oxidizing the organic compounds, through the release of the hydroxyl radicals, which lead to the mineralization of the organic matter releasing inorganic compounds, $\mathrm{CO}_{2}$ and $\mathrm{H}_{2} \mathrm{O}$. Among the most used AOP are the Fenton reaction, which occurs in the presence of $\mathrm{Fe}^{2+}$ ions, combined with a strong oxidizing agent, such as hydrogen peroxide $\left(\mathrm{H}_{2} \mathrm{O}_{2}\right)$; The photo-Fenton process, which in addition to the Fenton reagents employs ultraviolet (UV) or visible radiation; the $\mathrm{UV} / \mathrm{H}_{2} \mathrm{O}_{2}$ action, in which there is only the combination of $\mathrm{H}_{2} \mathrm{O}_{2}$ and radiation; and photolysis, that involves, only, the use of radiation (ARAÚJO et al, 2016). These processes act differently, depending on, among other factors, the pollutant in question.

In the case of the degradation of pharmaceuticals, studies have revealed that the processes involving the presence of radiation in conjunction with $\mathrm{H}_{2} \mathrm{O}_{2}$ present more satisfactory results (CARLSON et al, 2015; ALHARBI et al, 2017; NAPOLEÃO et al, 2018). This is because the radiation action leads to the photo-decomposition of this reagent, which generates hydroxyl radicals capable of promoting the oxidation of highly complex organic pollutants (NAVARRO; GABALDÓN; GÓMEZLOPEZ, 2017; LIMA; ALMEIDA; PAULA, 2016). Such decomposition mechanism is described in Equations 1 to 3 .

$$
\begin{aligned}
& \mathrm{H}_{2} \mathrm{O}_{2}+\mathrm{hv} \rightarrow 2 \cdot \mathrm{OH} \\
& \mathrm{OH}+\mathrm{OH} \rightarrow \mathrm{H}_{2} \mathrm{O}_{2} \\
& 2 \mathrm{H}_{2} \mathrm{O}_{2} \rightarrow 2 \mathrm{H}_{2} \mathrm{O}+\mathrm{O}_{2}
\end{aligned}
$$

The oxidizing power of hydroxyl radicals is often increased with the help of iron ions, which act to catalyze the reaction (BRITO; SILVA, 2012). In the photo-Fenton process, the hydroxyl radicals act to regenerate $\mathrm{Fe}^{3+}$ ions, which undergo a process of reduction (COSTA et al, 2014) according to Equation 4.

$$
\mathrm{Fe}^{3+}+\mathrm{H}_{2} \mathrm{O}_{2}+\mathrm{hv} \rightarrow \mathrm{Fe}^{2+}+\mathrm{H}^{+}+-\mathrm{OH}
$$

Studies on the combined performance of conventional treatments with AOP processes (Fenton process) to the degradation of phenol were able to promote a degradation of $99.7 \%$ of the compound, which presents in a recalcitrant way in aquatic matrices (SKORONSKI et al, 2015). In the same sense, 
the photo-Fenton process has also been shown to be efficient in the removal of pharmaceutical contaminants present in water. Giri and Golder (2015) observed the application of this type of treatment to the drug dipyrone and obtained a degradation of $96.40 \%$. Romero et al (2016) and Funai et al (2017) achieved $100.00 \%$ degradation by applying the same process to degrade the magnesium and sodium valproate drugs in aqueous medium.

In order to evaluate the percentage of degradation of the most diverse pollutants, it is necessary to have adequate analytical techniques. Among the most used ones is the chromatography, being the high-performance liquid chromatography (HPLC) used in the identification and quantification of pharmaceuticals (BIALK-BIELINSKA et al, 2016; PEAKE et al, 2016). To ensure greater reliability of the results, the methodology validation has been used, so that the analyzes can be said to be precise and accurate (ZANCHETA; PENA; GONÇALVES, 2015). Regarding the determination of organic matter levels, two parameters are the most applied, the chemical oxygen demand (COD) and the total organic carbon (TOC) (LUAN et al, 2017). It is based on the evaluation of these parameters that the kinetic monitoring of the degradation of pharmaceuticals by AOP is carried out. Based on that, the time in which the pollutants are mineralized can be determined (NAPOLEÃO et al, 2013).

Although advanced oxidative processes are well known and reported in the literature, it is sometimes difficult to clearly state the influence of the reaction parameters, especially when it is desired to apply such processes on an industrial scale. Based on this, some authors have made use of artificial neural networks (ANNs) to provide predictive models capable of adjusting nonlinear data of complex systems (JALIL et al, 2014; MORAES et al, 2016). Moraes et al (2016) state that a photooxidation process can be described efficiently through an ANN using the experimental data of total organic carbon as the output variable.

In addition to evaluating the parameters involved in AOP, their kinetic models and efficiency in the degradations of compounds considered to be persistent, recent studies show that just promoting the degradation is not enough. It is essential too, to carry out experiments evaluating the toxicity of the intermediates formed during the treatment (NAPOLEÃO et al, 2018). In this sense, researches have been carried out with the purpose of evaluating the environmental risks caused by the pollutants, as is the case of pharmaceuticals, compounds widely used by the population, which are often discarded in an improper way (VALCÁRCEL et al, 2011; PINTO et al, 2016).

Among the various classes of drugs studied are the anti-inflammatories, which includes nimesulide and ibuprofen. Nimesulide also has antipyretic and analgesic properties and is used in the treatment of febrile conditions, inflammatory processes related to the release of prostaglandins, besides being prescribed as an analgesic for dental infections and postoperative pain (SILVA; MENDONÇA; PARTATA, 2014). Ibuprofen is indicated for the relief of fever, trauma, headache, muscle and joint pain, as well as dental inflammation, sore throat and other symptoms associated with colds and flu (STOYANOVA, VINAROV, TCHOLAKOVA, 2016). These drugs are, therefore, widely used by the population, and somehow returned to the environment through the excretion process. In addition, they reach the environment coming from the production process itself, through the disposal of wastewater treatment plants of pharmaceutical industries (CHRISTOU et al, 2017; EBELE et al, 2017).

In this context, the present work aims to evaluate the efficiency of the degradation of nimesulide and ibuprofen in aqueous solution using different types of advanced oxidation processes. The study also sought to evaluate the most efficient AOP degradation kinetics, to use mathematical modeling using artificial neural networks and to verify the toxicity of the reaction intermediates against the 
seeds of Lactuta Sativa (lettuce), Cichorium endivia (chicory), Ocimum basilicum (basil) and Americano Hard grain (wheat).

\section{MATERIAL AND METHODS}

\subsection{Identification and quantification of the pharmaceuticals nimesulide and ibuprofen}

An analysis of the drugs under study was carried out in high performance liquid chromatography (HPLC) equipment (Shimadzu), with ultraviolet-visible (UV/Vis) detection system equipped with ULTRA C18 column $(5 \mu \mathrm{m} ; 4.6 \mathrm{~mm} \times 250 \mathrm{~mm})$ operating in reverse phase. The mobile phase employed a solution of acidified water with $0.1 \%$ acetic acid and acetonitrile with volumetric ratio of $65: 35$ and a flow of $0.700 \mathrm{~mL} \cdot \mathrm{min}^{-1}$. The oven temperature was maintained at $40 \pm 1^{\circ} \mathrm{C}$ and the pressure at 53 $\mathrm{kgf} \cdot \mathrm{cm}^{-2}$. Then, analytical curves were constructed in a concentration range between 0.1 and $1 \mathrm{mg} \cdot \mathrm{L}^{-1}$. The stock solution $\left(10 \mathrm{mg} \cdot \mathrm{L}^{-1}\right)$ of each pharmaceutical was prepared in a 9:1 mixture of acetonitrile and methanol.

Then, the methodology used was validated and the following parameters were analyzed: linearity, detection limit (LOD), quantification limit (LOQ), precision and accuracy. The linearity evaluation was performed based on the construction of the analytical curve and determination of the correlation coefficient (r). The precision of the method, based on the coefficient of variation (CV), as well as the accuracy were determined based on the recovery method, through the sample fortification procedure. The verification of the quantification and detection limits were performed according to INMETRO (2011). Equations 1 to 4 were used in the determination of such parameters and are set out in Table 1.

Table 1 - Equations used in the validation of the methodology

\begin{tabular}{|c|c|c|c|}
\hline Parameters & Variables & Equation & Number \\
\hline \multirow{2}{*}{ Precision } & \multirow{2}{*}{$\begin{array}{l}\mathrm{X}_{\mathrm{m}} \text { it's the arithmetic average of the } \\
\text { number of measurements, } \mathrm{x}_{\mathrm{i}} \text { the } \\
\text { individual value of the measurement } \\
\text { and } \mathrm{n} \text { the number of measurements. }\end{array}$} & $\mathrm{s}=\left(\sum\left(\mathrm{X}_{\mathrm{i}}-\mathrm{X}_{\mathrm{m}}\right)^{2} /(\mathrm{n}-1)\right)^{1 / 2}$ & (1) \\
\hline & & $\mathrm{CV}(\%)=\left(\mathrm{s} / \mathrm{X}_{\mathrm{m}}\right) \cdot 100$ & (2) \\
\hline Accuracy & $\begin{array}{l}\mathrm{C}_{1}, \mathrm{C}_{2} \text { and } \mathrm{C}_{3} \text { are the concentrations: } \\
\text { 1) determined in the sample with the } \\
\text { addition of the standard, 2) without } \\
\text { addition of the standard and 3) of the } \\
\text { standard added. }\end{array}$ & $\mathrm{R}(\%)=\left(\left(\mathrm{C}_{1}-\mathrm{C}_{2}\right) / \mathrm{C}_{3}\right) \cdot 100$ & (3) \\
\hline LOQ & \multirow{2}{*}{$\begin{array}{l}\mathrm{S} \text { is the estimate of the standard } \\
\text { deviation and } \mathrm{S} \text { the slope of the } \\
\text { analytical curve. }\end{array}$} & $\mathrm{LOQ}=10 \cdot(\mathrm{s} / \mathrm{S})$ & (4) \\
\hline LOD & & $\mathrm{LOD}=3.3 \cdot(\mathrm{s} / \mathrm{S})$ & (5) \\
\hline
\end{tabular}

\subsection{Deoradation of the nharmacenticals bv A PP 11sing hench reactors}

Degradation tests were performed using two types of advanced oxidative processes: photo-Fenton (tests containing iron) and $\mathrm{UV} / \mathrm{H}_{2} \mathrm{O}_{2}$ action (tests in absence of iron). For this, glass beakers $(80 \mathrm{~mL})$ filled with $50 \mathrm{~mL}$ of an aqueous solution containing the pharmaceuticals under study were used. 
Which were placed in a sunlight reactor, with 2 exhaust fans, operating with a 300W ultra-vilatux lamp of the OSRAM brand (Figure 1).

Figure 1 - Schematic representation of the bench reactor using sunlight


Source: Santana et al (2017)

The degradation of the drugs and the best working conditions were evaluated through a factorial design $2^{3}$ with central point (triplicate analysis). The independent variables studied were time, concentration of $\left(\left[\mathrm{H}_{2} \mathrm{O}_{2}\right]\right)$ (F. Maia) and concentration of iron ions ([Fe]) $\left(\mathrm{FeSO}_{4} \cdot 7 \mathrm{H}_{2} \mathrm{O}-\mathrm{Vetec}\right.$, being utilized as the iron source). Table 2 contains the planning matrix used in this work, as well as the description of factor levels. It will be seen from this Table that the tests 1 to 4 refer to the photoperoxidation process, whereas the tests 5 to 11 employ the photo-Fenton process.

Table 2 - Factorial design $2^{3}+$ central point (triplicate analysis)

\begin{tabular}{c|c|c|c}
\hline Test & \multicolumn{1}{c}{ Time (h) } & {$\left[\mathrm{H}_{2} \mathrm{O}_{2}\right]\left(\mathbf{m g} \cdot \mathbf{L}^{-1}\right)$} & [Fe] $\left(\mathbf{m g} \cdot \mathbf{L}^{-1}\right)$ \\
\hline 1 & $-(1)$ & $-(14)$ & - (absence of iron) \\
\hline 2 & $+(3)$ & $-(14)$ & - (absence of iron) \\
\hline 3 & $-(1)$ & $+(28)$ & - (absence of iron) \\
\hline 4 & $+(3)$ & $+(28)$ & - (absence of iron) \\
\hline 5 & $-(1)$ & $-(14)$ & $+(4.4)$ \\
\hline 6 & $+(3)$ & $-(14)$ & $+(4.4)$ \\
\hline 7 & $-(1)$ & $+(28)$ & $+(4.4)$ \\
\hline 8 & $+(3)$ & $+(28)$ & $+(4.4)$ \\
\hline 9 & $0(2)$ & $0(21)$ & $0(2.2)$ \\
\hline 10 & $0(2)$ & $0(21)$ & $0(2.2)$ \\
\hline 11 & $0(2)$ & $0(21)$ & $0(2.2)$ \\
\hline
\end{tabular}


The identification of the working condition was performed through the analysis of total organic carbon (TOC) and chemical oxygen demand (COD). The first of the analyzes was quantified on a Shimadzu high sensitivity TOC equipment (TOC-Vcsh model), with a concentration range of $4 \mathrm{ng} \cdot \mathrm{L}^{-1} \mathrm{a}$ $25.000 \mathrm{mg} \cdot \mathrm{L}^{-1}$. The determination of TOC was done indirectly, from the difference between total carbon (TC) and total inorganic carbon (TIC), while the COD measurements were performed using the $5220 \mathrm{D}$ spectrophotometric method contained in the Standard methods for the examination of water and wastewater (APHA, 2012).

After the best working condition was determined, the degradation of the drugs via HPLC was evaluated. For this analysis, the solutions underwent an extraction step employing strata-X polymer cartridges operating in reverse phase $(500 \mathrm{mg} / 6 \mathrm{~mL}$ - Allcrom). The stationary phase was conditioned with two aliquots of $5 \mathrm{~mL}$ of acetonitrile (J.T.Baker), and two aliquots of $5 \mathrm{~mL}$ of ultra-pure water.

\subsection{Kinetic study: adequacy to the grouped kinetic model}

In the best working conditions, identified in the factorial design study, tests were carried out to quantify the kinetic evolution of TOC as a function of time. The suitability of the proposed study to the lumped kinetic model (LKM) was evaluated (ZHANG; CHUANG, 1999). This model describes the profile of the total residual concentration in terms of carbon contained in the liquid phase $(\mathrm{Cr})$, dividing the species formed into three: A) encompasses the pharmaceuticals and intermediates susceptible to oxidation (non-refractory), B) represents the refractory organic species arising from the oxidation of $\mathrm{A}$ and $\mathrm{C}$ ) involves all the carbon dioxide formed from the complete oxidation of organic species.

\subsection{Mathematical evaluation: application of artificial neural network}

In the artificial neural network was simulated to predict the conversion of TOC, using as input parameters, time, $\mathrm{H}_{2} \mathrm{O}_{2}$ concentration, iron ions concentration and chemical oxygen demand analyzes. In the ANN construction, to approximate the forward transmission characteristics, a multilayer perceptron (MLP) type configuration was used. For this, the propagation of the network input signal was performed through the neurons distributed in it, as well as in the hidden layer and its output. The MLP used the learning of the backpropagation algorithm of the network, guaranteeing a greater convergence in its learning.

\subsection{Toxicity assessment}

Knowing that after the use of the AOP, intermediates are formed, the toxicity of the treated solution, as well as the samples before treatment, were evaluated using the seeds of Lactuta Sativa (lettuce), Cichorium endívia (chicory), Ocimum basilicum (basil) and Americano Hard grain (wheat). For the bioassays were used Petri dishes filled with filter paper, in which 10 seeds and $2 \mathrm{~mL}$ of the test solution were placed in each plate. Deionized water was used as negative control and a $3 \%$ boric acid solution as positive control. The Petri dishes were kept at $25 \pm 1^{\circ} \mathrm{C}$, in the absence of light, for a period of $72 \mathrm{~h}$ (grain) and $120 \mathrm{~h}$ (seeds). Finally, after the incubation time, the number of germinated seeds and the root growth of each one was observed. Then, the relative growth rate (RGR) and germination index (GI) were calculated according to the methodology proposed by Young et al, 2012. 


\section{RESULTS AND DISCUSSION}

\subsection{Identification, quantification and validation of the methodology of the drugs nimesulide and ibuprofen}

The pharmaceuticals nimesulide and ibuprofen were analyzed together and observed by HPLC at the wavelengths of 264 and $223 \mathrm{~nm}$, respectively (Figure 3). Such compounds were identified in a retention time range of 3.5 to $6.0 \mathrm{~min}$, which agrees with Maltese; Maugeri; Bucolo (2004) who observed nimesulide in 5.9 min and with Eraga et al (2015) who observed ibuprofen in a time of 3.6 min. Once the suitability of the proposed methodology to identify the drugs under study was verified, the validation step was carried out to guarantee the reliability of the quantification process.

Figure 3 - Chromatograms of the drugs nimesulide and ibuprofen



It is noteworthy that the determination of the nimesulide drug is carried out on the ultraviolet scale since this pharmaceutical has in its molecular structure a weakly acidic methanesulfonamide group, which dissociates the $\mathrm{pH}$ dependence of the reaction medium. Pereira et al (2011) also stated that when performing a determination of $\mathrm{pKa}$ of nimesulide by spectrophotometry, at $\mathrm{pH}$ values between 2 and 10, the presence of isosbestic peaks around $270 \mathrm{~nm}$ and $340 \mathrm{~nm}$ is observed, ensuring that the species can be evaluated with the same safety in both. As for ibuprofen, Borges; Goraieb; Collins (2012) states that at $\mathrm{pH}$ between 5 and 7 there are no major chances in the pKa value, so the range used in this work does not compromise the spectrophotometric analysis.

From the dilutions of the stock solution, the analytical curves were constructed, taking as response the areas of the different concentrations analyzed. To evaluate the dispersion of the values of these concentrations, a statistical analysis was performed, based on the calculation of the standard deviation between them, using Grubbs test for 95\% confidence (GRUBBS; BECK, 1972). 
Table 3 - Average of the areas, standard deviation and Grubbs test for the pharmaceuticals under study

\begin{tabular}{|c|c|c|c|c|c|c|c|c|}
\hline \multirow{3}{*}{$\begin{array}{l}\text { Concen- } \\
\text { tration } \\
\left(\mathrm{mg} \cdot \mathrm{L}^{-1}\right)\end{array}$} & \multicolumn{4}{|c|}{ Nimesulide } & \multicolumn{4}{|c|}{ Ibuprofen } \\
\hline & \multirow{2}{*}{$\begin{array}{l}\text { Average of } \\
\text { the areas }\end{array}$} & \multirow{2}{*}{$\begin{array}{l}\text { Standard } \\
\text { deviation }\end{array}$} & \multicolumn{2}{|c|}{ Grubbs Test } & \multirow{2}{*}{$\begin{array}{c}\text { Average of } \\
\text { the areas }\end{array}$} & \multirow{2}{*}{$\begin{array}{l}\text { Standard } \\
\text { deviation }\end{array}$} & \multicolumn{2}{|c|}{ Grubbs test } \\
\hline & & & $\mathrm{G}_{<}$ & G> & & & $\mathrm{G}_{<}$ & $\mathrm{G}_{>}$ \\
\hline 10 & 1102602 & 46589 & 1.311 & 1.630 & 1075693 & 16769 & 1.180 & 1.729 \\
\hline 20 & 2208718 & 116505 & 1.275 & 1.314 & 2157020 & 37119 & 1.260 & 1.342 \\
\hline 40 & 4541918 & 95301 & 1.331 & 1.243 & 4380899 & 80476 & 1.818 & 1.312 \\
\hline 50 & 5329161 & 393931 & 1.938 & 0.913 & 5471956 & 49130 & 1.014 & 1.829 \\
\hline 60 & 6598530 & 588214 & 1.605 & 1.174 & 6327920 & 70675 & 1.617 & 1.250 \\
\hline 70 & 8418863 & 207781 & 1.096 & 1.445 & 7328667 & 92943 & 1.470 & 1.540 \\
\hline 80 & 9366057 & 594617 & 1.219 & 1.172 & 8488089 & 158593 & 1.455 & 1.255 \\
\hline 100 & 11881879 & 215707 & 1.758 & 0.795 & 10423081 & 132415 & 1.473 & 1.161 \\
\hline
\end{tabular}

*Manual integration method was used to determine peak areas.

Based on the results obtained and described in Table 3, it was possible to verify that the obtained values agreed with each other in the Grubbs test for $97.5 \%$ of confidence. It should be noted that for eight measurements and the confidence level chosen, the values of $G<$ and $G$ > should be less than 2.126 (GRUBBS; BECK, 1972).

Since the data obtained were coherent, the analysis of linearity was done by constructing the analytical curve and calculating the correlation coefficient ( $\mathrm{r}$ ), as can be observed in Figure 4. It was verified that the analytical curves presented $\mathrm{r}$ values of 0.9955 (nimesulide) and 0.9991 (ibuprofen), obeying the standards required by the National Health Surveillance Agency (ANVISA), which considers linear when $r \geq 0.99$, while the National Institute of Metrology, Standardization and Industrial Quality (INMETRO) accepts $r \geq 0.90$ (INMETRO, 2011; BRASIL, 2011).

Figure 4 - Analytical curves of the pharmaceuticals: a) nimesulide e b) ibuprofen

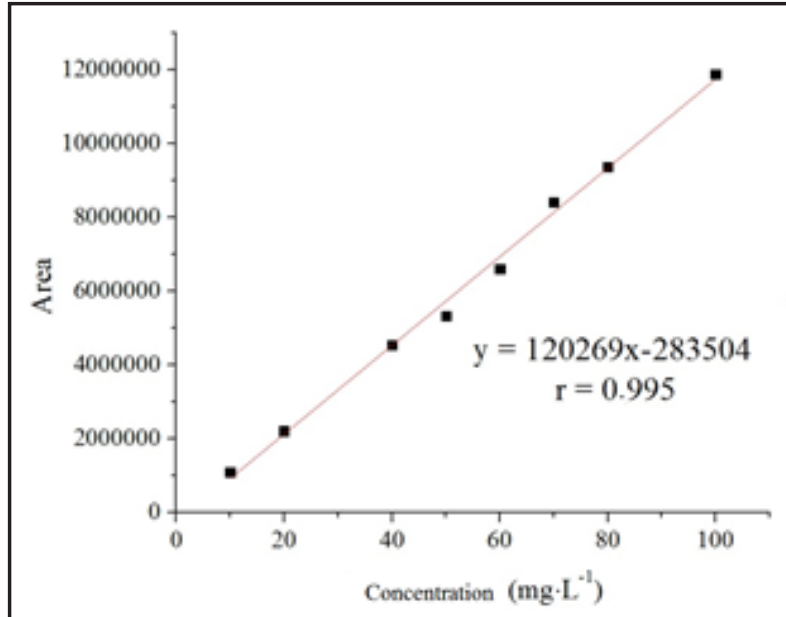

(a)

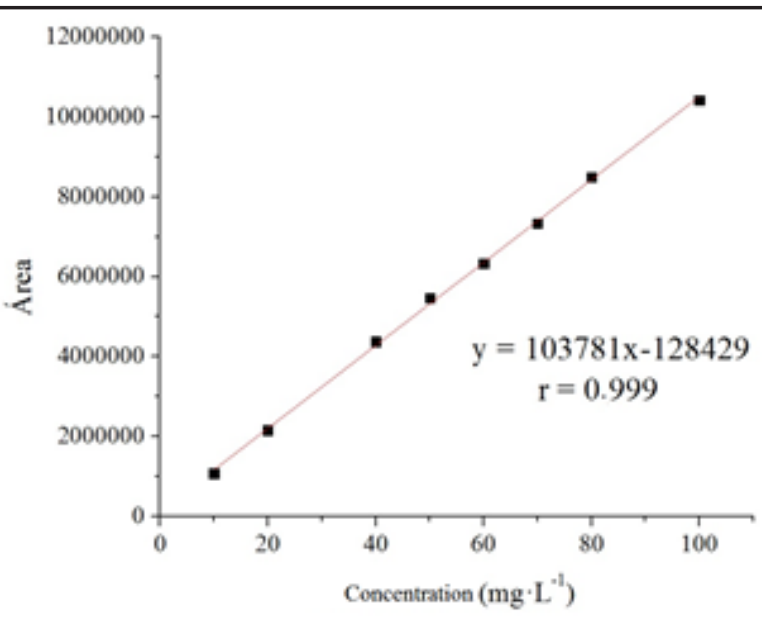

(b)

After verifying the linearity of the method for the two pharmaceuticals, the precision was analyzed, based on the quantification of the coefficient of variation. The CV values obtained for each one of the concentrations are described in Table 4. 
Table 4 - Values obtained for the coefficient of variation

\begin{tabular}{c|c|c|c|c|c}
\hline $\begin{array}{c}\text { Concentration } \\
\left(\mathbf{m g} \cdot \mathbf{L}^{-1}\right)\end{array}$ & Nimesulide & Ibuprofen & $\begin{array}{c}\text { Concentration } \\
\left(\mathbf{m g} \cdot \mathbf{L}^{-1}\right)\end{array}$ & Nimesulide & Ibuprofen \\
\hline $\mathbf{1 0}$ & 4.22 & 1.56 & $\mathbf{6 0}$ & 8.91 & 1.12 \\
\hline $\mathbf{2 0}$ & 5.27 & 1.72 & $\mathbf{7 0}$ & 2.47 & 1.27 \\
\hline $\mathbf{4 0}$ & 2.10 & 1.84 & $\mathbf{8 0}$ & 6.35 & 1.87 \\
\hline $\mathbf{5 0}$ & 7.39 & 0.90 & $\mathbf{1 0 0}$ & 1.81 & 1.27 \\
\hline
\end{tabular}

In order for the method to be considered precise, it is necessary that the values of $\mathrm{CV}$ are lower than $20 \%$, which was observed for all concentrations analyzed (INMETRO, 2011). Then the analysis of the accuracy of the method was performed, and the following percentages of recuperation were verified: 97, 103 and 97 for nimesulide and 93, 103 and 118 for ibuprofen. Therefore, an average of $99.0 \pm 3.5$ for nimesulide and $104.7 \pm 12.6$ for ibuprofen was obtained, which confirms that the analytical method is accurate, since the recovery percentages obtained are between 50 and $120 \%$ (SOUZA, 2011; PERLATTI et al, 2012). Finally, the quantification and detection limits of the methods were determined: a) nimesulide $\mathrm{LOQ}=11.83 \mathrm{mg} \cdot \mathrm{L}^{-1}$ and $\mathrm{LOD}=3.58 \mathrm{mg} \cdot \mathrm{L}^{-1} \mathrm{e} \mathrm{b}$ ) ibuprofen $\mathrm{LOQ}=16.15$ $\mathrm{mg} \cdot \mathrm{L}^{-1}$ and $\mathrm{LOD}=5.33 \mathrm{mg} \cdot \mathrm{L}^{-1}$.

\subsection{Degradation of pharmaceuticals by AOP using bench reactor}

Initially, for an aqueous solution containing the drug mixture nimesulide $\left(50 \mathrm{mg} \cdot \mathrm{L}^{-1}\right)$ and ibuprofen (50 $\left.\mathrm{mg} \cdot \mathrm{L}^{-1}\right)$ the efficiency of the direct photolysis process was evaluated and an organic matter conversion on less than $40 \%$ was verified for both compounds. Subsequently, this same solution was subjected to COD analysis, as well as total organic carbon before and after the degradation process. In order to verify the best working condition, a study of factorial planning was carried out, the results which are show in Table 5.

Table 5 - Results of the tests carried out for factorial design $2^{3}$ for the conversion of organic matter (COD and TOC)

\begin{tabular}{c|c|c|c|c}
\hline Test & $\begin{array}{c}\text { TOC } \\
\left(\mathbf{m g ~ d e ~} \mathbf{~}_{\mathbf{2}} \cdot \mathbf{L}^{-1}\right)\end{array}$ & $\begin{array}{c}\text { \% of conversion of } \\
\text { COD }\end{array}$ & $\begin{array}{c}\text { TOC } \\
\left(\mathbf{m g C} \cdot \mathbf{L}^{-1}\right)\end{array}$ & $\begin{array}{c}\text { \% de conversion of } \\
\text { COD }\end{array}$ \\
\hline $\mathbf{1}$ & 29120.0 & 34.37 & 1258.0 & 44.43 \\
\hline $\mathbf{2}$ & 8154.0 & 81.63 & 454.4 & 79.93 \\
\hline $\mathbf{3}$ & 27704.0 & 37.56 & 1214.0 & 46.37 \\
\hline $\mathbf{4}$ & 9537.0 & 78.50 & 534.8 & 76.37 \\
\hline $\mathbf{5}$ & 11070.0 & 75.05 & 632.0 & 72.08 \\
\hline $\mathbf{6}$ & 6904.0 & 84.44 & 436.2 & 80.73 \\
\hline $\mathbf{7}$ & 9587.0 & 78.39 & 575.8 & 77.16 \\
\hline $\mathbf{8}$ & $\mathbf{3 7 2 9 . 0}$ & $\mathbf{9 1 . 6 0}$ & $\mathbf{2 3 3 . 8}$ & $\mathbf{8 9 . 6 7}$ \\
\hline $\mathbf{9}$ & 9770.0 & 77.98 & 579.2 & 74.41 \\
\hline $\mathbf{1 0}$ & 9070.0 & 79.55 & 558.3 & 75.34 \\
\hline $\mathbf{1 1}$ & 9436.0 & 78.30 & 573.4 & 74.67 \\
\hline
\end{tabular}


The analysis of Table 5 allows to verify that the test that presented the best result was number 8 , where $91.60 \%$ of COD conversion and $89.67 \%$ of TOC were observed, this experiment was carried out under the following conditions: time of 3 hours; $\left[\mathrm{H}_{2} \mathrm{O}_{2}\right]=$ de $0.12 \mathrm{~g} \cdot \mathrm{L}^{-1} \mathrm{e}[\mathrm{Fe}]=0.43 \mathrm{~g} \cdot \mathrm{L}^{-1}$. Thus, for a better evaluation of the data, a statistical analysis was performed by calculating the effects of the factors and their interactions with the Statistica 6.0 program. These identified which of the effects were statistically significant for $95 \%$ confidence by constructing Pareto charts (Figure 5).

It is worth noting that, in order to verify that there was no interference of the hydroxyl radicals in the COD analysis, residual peroxide tests were performed using a colorimetric method with Mquant test strips (Merck), with $\mathrm{H}_{2} \mathrm{O}_{2}$ ranging from 0 to $25 \mathrm{mg}$. $\mathrm{L}^{-1}$. It was then verified that the amount of $\mathrm{H}_{2} \mathrm{O}_{2}$ residual at the end of the treatment was less than $1 \mathrm{mg} . \mathrm{L}^{-1}$, and the analysis of the organic matter could be performed without interference from the reagents. Similarly, the residual iron concentration presented was properly precipitated with $\mathrm{NaOH}(0,1 \mathrm{M})$ by raising the reaction $\mathrm{pH}$ to the basic medium so as not to interfere with the TOC analysis.

Figure 5 - Pareto charts referring to the degradation of the pharmaceuticals a) COD conversion e b) TOC conversion

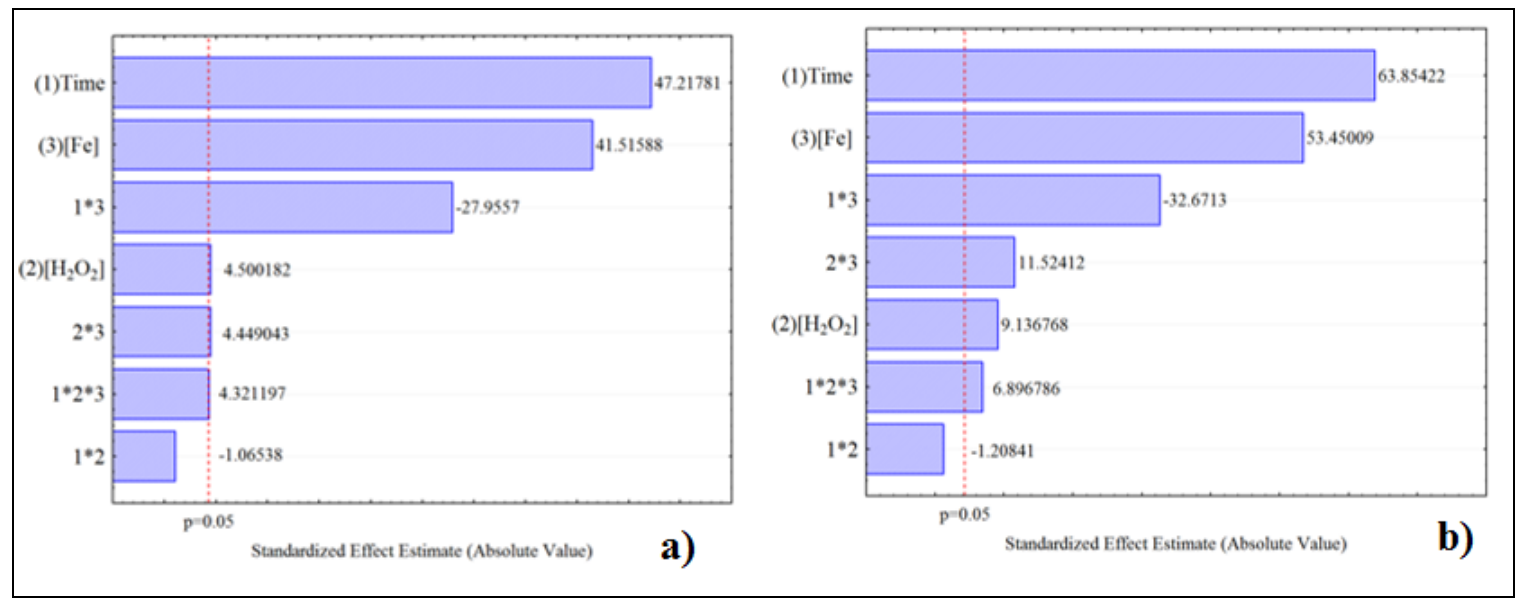

The analysis of figures $5 a$ ) and $5 b$ ) indicates that all major effects were statistically significant at $95 \%$ confidence as well as interactions effects, except for the interaction between $\left[\mathrm{H}_{2} \mathrm{O}_{2}\right]$ and time. Thus, for a better understanding of the behavior of the interactions between the variables studied in the conversion of COD and TOC, surface graphs were generated, which can be observed in Figure 6 .

The analysis of Figures 6a) and 6e) indicates that the interaction of time and $\left[\mathrm{H}_{2} \mathrm{O}_{2}\right]$ variables does not show large variations in the values of organic matter conversion, confirming that observed in the Pareto charts. (Figure 5). When analyzing Figures 6b) and 6f) it is verified that when the highest levels of $[\mathrm{Fe}]$ and $\left[\mathrm{H}_{2} \mathrm{O}_{2}\right]$ are combined, a greater conversion of COD and TOC is obtained. Finally, when analyzing the combination between $[\mathrm{Fe}]$ and time, it is observed that a higher conversion is observed for the combination between the higher levels of the two analyzed variables (Figures 6c) and 6g)). Thus, it can be stated that the working conditions obtained in the present study, regarding the iron concentration value, meet the water release standards established by the resolution of National Environmental Council (CONAMA) number 430/2011, indicating that the [Fe] should be less than 15 $\mathrm{mg} \cdot \mathrm{L}^{-1}(\mathrm{CONAMA}, 2011)$. 
Determined the best process conditions $\left(\left[\mathrm{H}_{2} \mathrm{O}_{2}\right]=28.0 \mathrm{mg} \cdot \mathrm{L}^{-1}\right.$ and $\left.[\mathrm{Fe}]=4.4 \mathrm{mg} \cdot \mathrm{L}^{-1}\right)$, a kinetic study of the pharmaceuticals degradation using the photo-Fenton process was carried out. For this study, the total organic carbon concentrations were used as response to verify the adequacy to the grouped kinetic model, as well as to evaluate the application of artificial neural networks to predict a mathematical model.

Figure 6 - Response Surface of the interaction: a) and e) $\left[\mathrm{H}_{2} \mathrm{O}_{2}\right]$ and time; b) and f) $[\mathrm{Fe}]$ and $\left[\mathrm{H}_{2} \mathrm{O}_{2}\right]$; c) and g) $[\mathrm{Fe}]$ and time

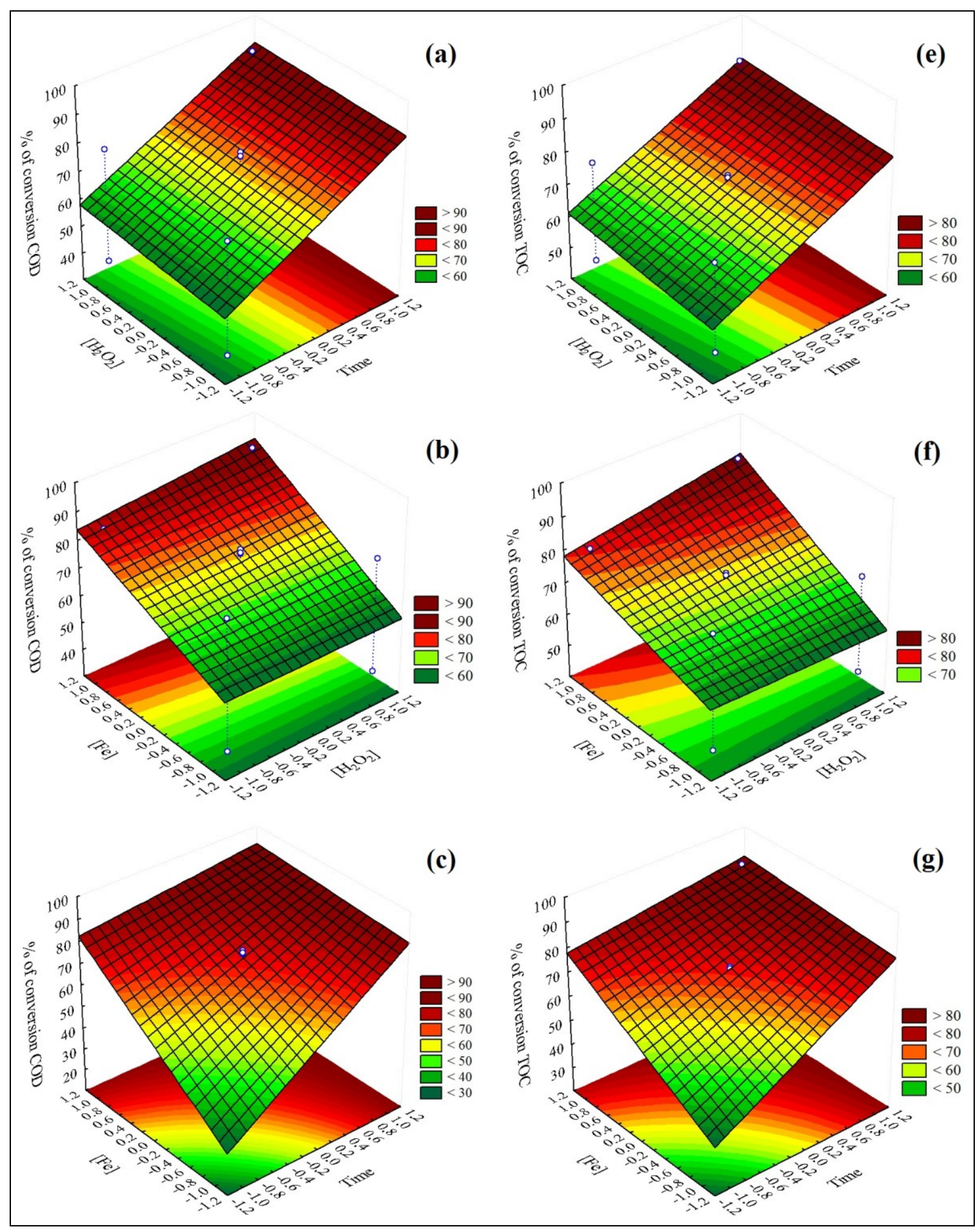




\subsection{Kinetic study: adequacy to the grouped kinetic model}

In the best working condition, the concentrations of the two drugs under study were evaluated by HPLC, finding that the photo-Fenton process degraded $89.70 \%$ of nimesulide and $93.35 \%$ of ibuprofen. Based on the best experimental conditions described above, a kinetic study was carried out by monitoring the total organic carbon concentration. The description of the experimental results for the TOC concentration together with the relation between the TOC and the initial TOC (TOC 0$)$ are described in Table 6.

Table 6 - Evolution of TOC concentration over time and the ratio of TOC to the initial TOC (TOC0), observed and calculated

\begin{tabular}{c|c|c|c}
\hline $\begin{array}{c}\text { Time } \\
(\mathbf{m i n})\end{array}$ & $\begin{array}{c}\text { TOC } \\
\left(\mathbf{m g C} \cdot \mathbf{L}^{-1}\right)\end{array}$ & TOC/TOC (observed) & $\begin{array}{c}\text { TOC/TOC } \\
\text { (calculated) }\end{array}$ \\
\hline $\mathbf{0}$ & 6053.00 & 1.00 & 1.00 \\
\hline $\mathbf{1 5}$ & 5462.00 & 0.90 & 0.91 \\
\hline $\mathbf{3 0}$ & 4855.00 & 0.80 & 0.82 \\
\hline $\mathbf{6 0}$ & 4003.00 & 0.66 & 0.63 \\
\hline $\mathbf{1 2 0}$ & 2148.00 & 0.35 & 0.35 \\
\hline $\mathbf{1 8 0}$ & 921.50 & 0.15 & 0.19 \\
\hline $\mathbf{2 4 0}$ & 608.70 & 0.10 & 0.10 \\
\hline $\mathbf{3 6 0}$ & 602.80 & 0.10 & 0.03 \\
\hline
\end{tabular}

By analyzing Table 6 it is possible to verify that a conversion of $90.04 \%$ of the organic matter was reached after $360 \mathrm{~min}\left([\mathrm{COT}]=602.80 \mathrm{mgC} \cdot \mathrm{L}^{-1}\right)$. With these data, we could then verify the adequacy to the kinetic group model as well as to determine the apparent velocity constants $k_{1}$, $k_{2}$, e $k_{3}$ from Equation 8. The values of the constants were obtained through non-linear interpolation applied to the data found using the Microsoft Office Excel solver tool. The method of minimizing the quadratic sum of the residues was used in the software.

$\left(\mathrm{TOC} / \mathrm{TOC}_{0}\right)=\mathrm{C}_{\mathrm{r}}=\left[\left(\mathrm{k}_{1}-\mathrm{k}_{3}\right) /\left(\mathrm{k}_{1}+\mathrm{k}_{2}-\mathrm{k}_{3}\right)\right] \mathrm{e}^{-\left(\mathrm{k}_{1}+\mathrm{k}_{2}\right) \mathrm{t}}+\left[\mathrm{k}_{2} /\left(\mathrm{k}_{1}+\mathrm{k}_{2}-\mathrm{k}_{3}\right)\right] \mathrm{e}^{-\mathrm{k} 3 \mathrm{t}}$

Thus, based on Equation 8, the values of $\mathrm{k}_{1}$, $\mathrm{k}_{2}$ e $\mathrm{k}_{3}$ were determined being respectively $0.024 \mathrm{~min}^{-1}$, $0.010 \mathrm{~min}^{-1} \mathrm{e} 0.005 \mathrm{~min}^{-1}$. These results indicate that the mineralization of the pharmaceuticals plus the non-refractory intermediates $\left(\mathrm{k}_{1}=0.024 \mathrm{~min}^{-1}\right)$ occurs at a higher reaction rate than the degradation in refractory intermediates $\left(\mathrm{k}_{2}=0.010 \mathrm{~min}^{-1}\right)$. However, the mineralization of the refractory intermediates has a lower reaction rate $\left(\mathrm{k}_{3}=0.005 \mathrm{~min}^{-1}\right)$ than the other reactions involved. This indicates that the group of pharmaceuticals plus the non-refractory intermediates has a greater tendency of mineralization when compared to the formation of refractory intermediates. Thus, the graphs for the adjusted kinetic model fit and the comparative analysis of the theoretical and experimental TOC values can be constructed, as can be observed in Figure 7. 
Figure 7 - a) Adjustment of the kinetic model grouped to the experimental data of the TOC conversion; b) Comparison between theoretical and experimental TOC values

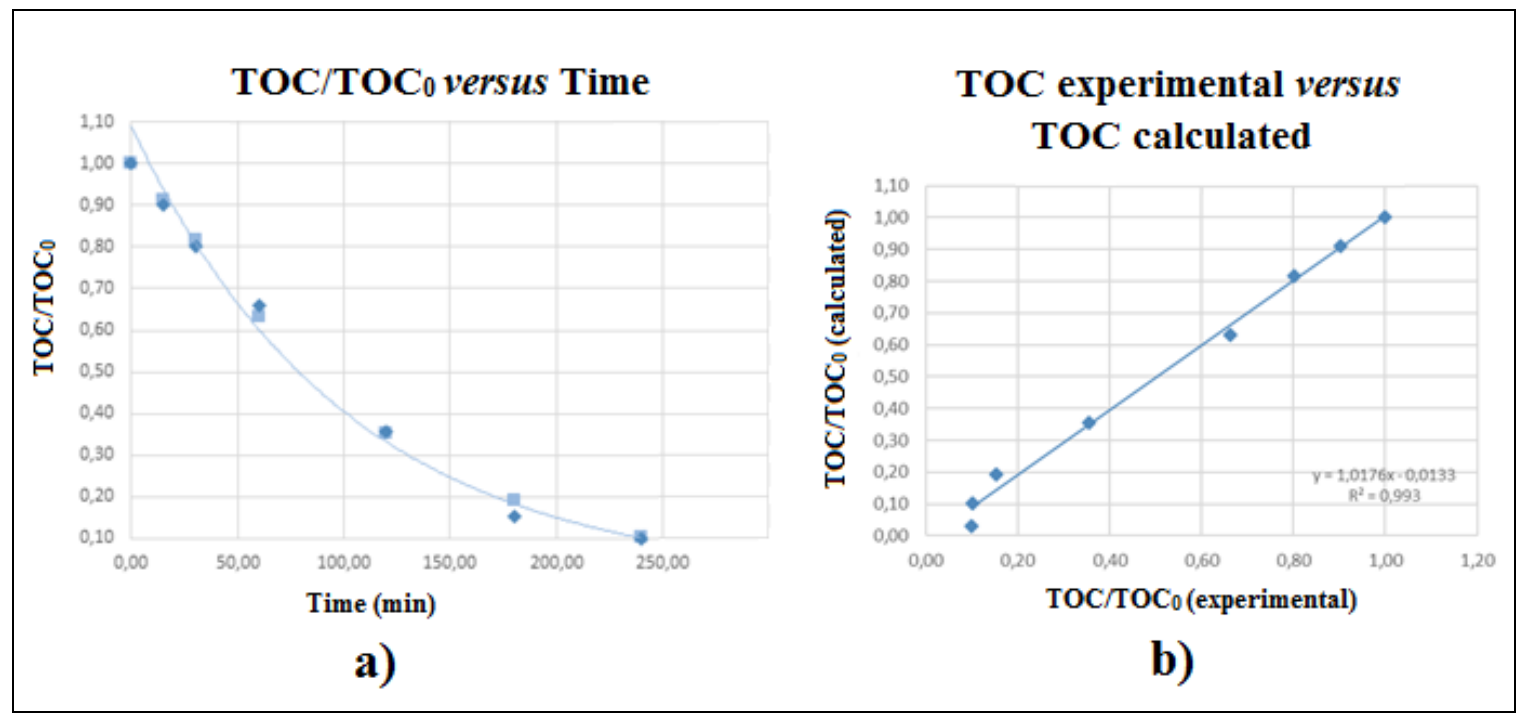

Figure 7 show a good correlation between the data obtained experimentally and the calculated theoretical data, indicating that the adopted kinetic model can be applied satisfactorily to the TOC conversion over time. This verification is corroborated by the value of the linear regression coefficient $\left(R^{2}\right)$ that was equal to 0.993 .

\subsection{Mathematical evaluation: application of artificial neural networks}

Once the kinetic data for degradation of the pharmaceuticals ibuprofen and nimesulide were found to be well adapted to the grouped kinetic model, the mathematical evaluation using artificial neural networks was applied. The descriptive statistics of the five variables used in ANN are contained in Table 7.

Table 7 - Descriptive statistics of the five variables used in ANN

\begin{tabular}{|c|c|c|c|c|c|c|c|c|c|c|c|c|}
\hline \multirow{2}{*}{ Variables } & \multicolumn{4}{|c|}{ Training } & \multicolumn{4}{|c|}{ Test } & \multicolumn{4}{|c|}{ Validation } \\
\hline & Min & $\operatorname{Max}$ & Average & $\sigma$ & Min & Max & Average & $\sigma$ & Min & Max & Average & $\sigma$ \\
\hline $\begin{array}{c}\text { Tempo } \\
\text { (min) }\end{array}$ & 0.00 & 360.00 & 122.86 & 86.28 & 0.00 & 360.00 & 155.00 & 129.03 & 0.00 & 300.00 & 146.67 & 106.49 \\
\hline $\begin{array}{l}{\left[\mathrm{H}_{2} \mathrm{O}_{2}\right]} \\
\left(\mathrm{mg} \cdot \mathrm{L}^{-1}\right)\end{array}$ & 14.00 & 28.00 & 23.67 & 5.77 & 28.00 & 28.00 & 28.00 & 0.00 & 14.00 & 28.00 & 22.56 & 6.65 \\
\hline $\begin{array}{c}{\left[\mathrm{Fe}^{2+}\right]} \\
\left(\mathrm{mg}^{2} \mathrm{~L}^{-1}\right)\end{array}$ & 0.00 & 4.40 & 2.93 & 1.86 & 0.00 & 4.40 & 3.42 & 1.94 & 2.20 & 4.40 & 4.16 & 2.09 \\
\hline $\operatorname{COD}(\%)$ & 0.00 & 91.60 & 65.12 & 23.95 & 0.00 & 86.82 & 55.27 & 30.87 & 0.00 & 85.73 & 67.73 & 36.31 \\
\hline TOC(\%) & 0.00 & 90.04 & 63.08 & 26.07 & 0.00 & 90.04 & 60.23 & 36.09 & 0.00 & 89.99 & 68.65 & 40.26 \\
\hline
\end{tabular}

Min = minimum, Max = maximum, $\sigma=$ standard deviation

Through the analysis of Table 7 it is possible to verify in the training and in the test a conversion of $90.04 \%$, while in the validation the conversion rate of total organic carbon was $89.99 \%$. The optimization of the ANN topology is probably the most important step in the development of the 
model. In the present work, a three-layer posterior propagation neural network (4:4:1) was used to model organic matter conversion. Figure 8 shows the architecture diagram ANN MLP 4-4-1 BFGS 4567.

Figure 8 - Architecture diagram ANN MLP 4-4-1 BFGS 4567

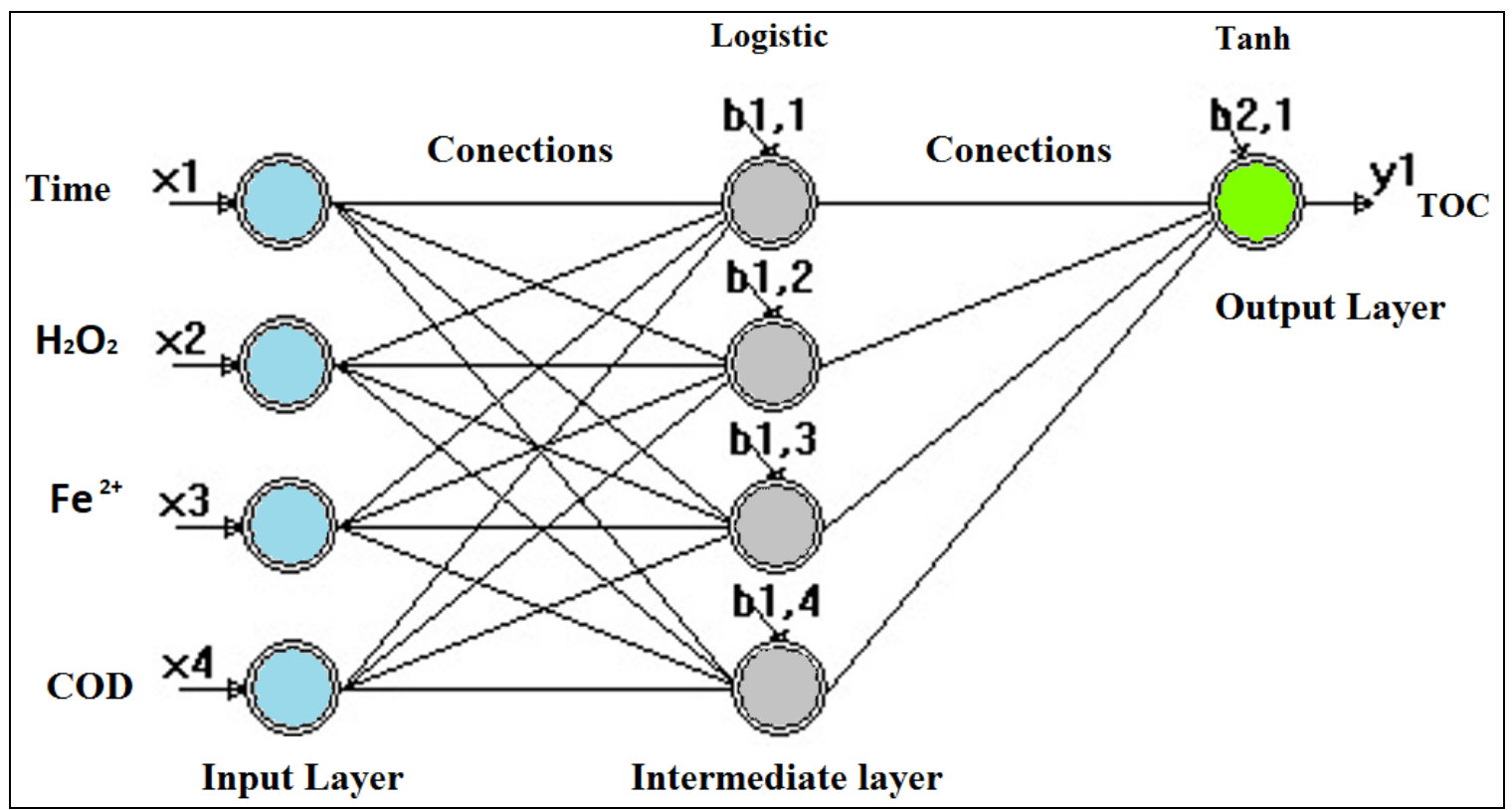

Thus, the ANN for the photo-Fenton/sunlight system used in the degradation of nimesulide and ibuprofen pharmaceuticals presented a linear regression coefficient $\left(R^{2}\right)$ equal to 1.00 for training, testing and validation when using MLP model 4-1-1. The training algorithm used was the BFGS 4567, the SOS error function, using as an activation function an internal layer logistic and output Tanh.

To calculate training, validation and test errors, all outputs were performed on an inverse interval scale to return the predicted responses to their original scale. Then, these data were compared with the values obtained experimentally. The ANN used in this work provided the weights listed in Table 8.

Table 8 - Values of the weights of the entry, intermediates and exit layers of ANN MLP 4-4-1

(BFGS 4567, Logistic - Tanh)

\begin{tabular}{c|c|c|c|c|c|c}
\hline \multirow{2}{*}{ Neuron } & \multicolumn{7}{c}{ Weights } \\
\cline { 2 - 7 } & Time (min) & $\begin{array}{c}{\left[\mathrm{H}_{2} \mathrm{O}_{2}\right]} \\
(\mathbf{m g . L}\end{array}$ & $\begin{array}{c}{\left[\mathrm{Fe}^{2+} \mathbf{)}\right.} \\
\left(\mathbf{m g . L}^{-1}\right)\end{array}$ & $\begin{array}{c}\text { COD } \\
(\%)\end{array}$ & $\begin{array}{c}\text { Bias } \\
\text { input }\end{array}$ & $\begin{array}{c}\text { TOC } \\
\text { conversion (\%) }\end{array}$ \\
\hline 1 & 1.3351 & 2.4592 & 6.9613 & 2.7625 & -15.8208 & 66.5294 \\
\hline 2 & -3.1948 & -34.9400 & -35.4083 & 36.8891 & 7.7467 & 1.3869 \\
\hline 3 & 29.3356 & 12.3996 & -4.7303 & 15.4220 & -6.4942 & 46.0932 \\
\hline 4 & -30.9336 & -24.3306 & 2.1527 & 27.7620 & 21.0440 & -14.4343 \\
\hline \multicolumn{7}{|c|}{ Bias intermediate } \\
\hline
\end{tabular}

Figure 8 shows the graph comparison between the experimental results and the simulated values by the MLP network (BFGS 4567). The analysis of this Figure allows to verify a good adequacy of the experimental results, being able to affirm that the ANN used is accurate. 


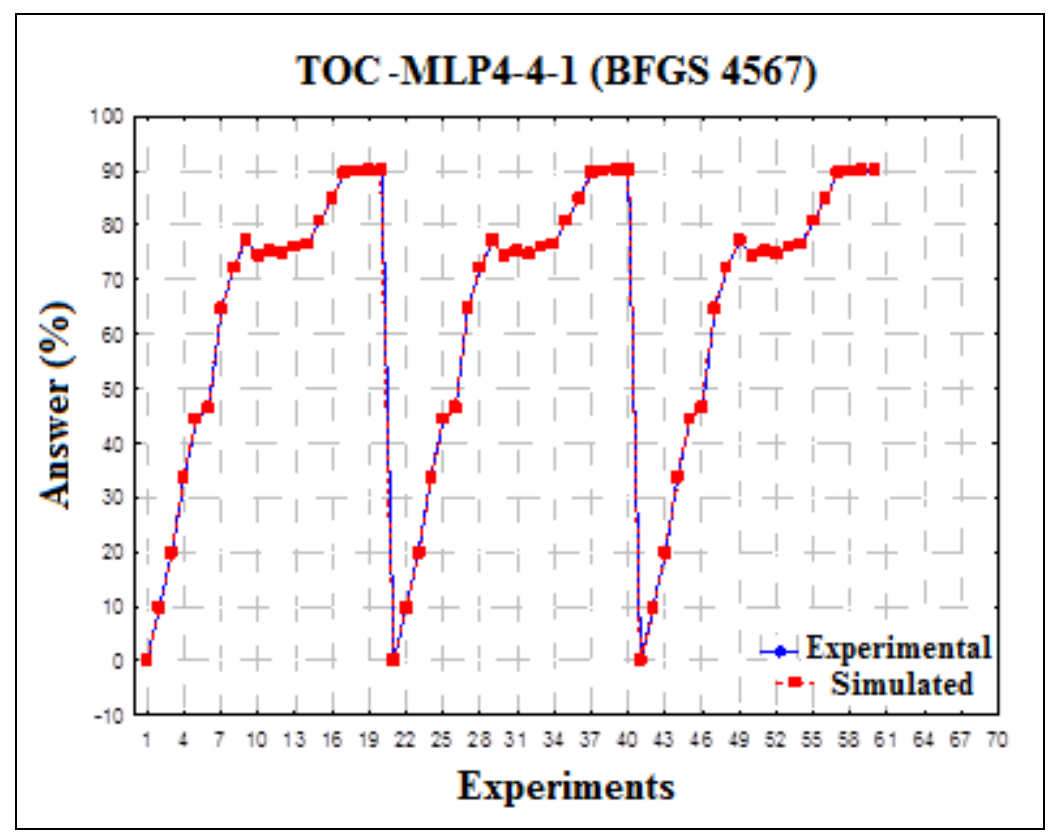

After analyzing Figure 9 and verifying the fit of the experimental data to the simulated values by the MLP network (BFGS 4567), the linear and residual regression graphs were generated (Figure 10). In Figure 10a) it can be verified that the prediction model presented a good fit, with a linear regression coefficient $\left(\mathrm{R}^{2}\right)$ equal to 1.000 , confirming that the neural network model reproduces the conversion of the TOC in the system, within the ranges used in the assembly model.

Figure 10 - a) Linear regression between the experimental and simulated results of MLP ANN (BFGS 4567), b) Residues of the conversion of experimental TOC and simulated by ANN MLP (BFGS 4567)
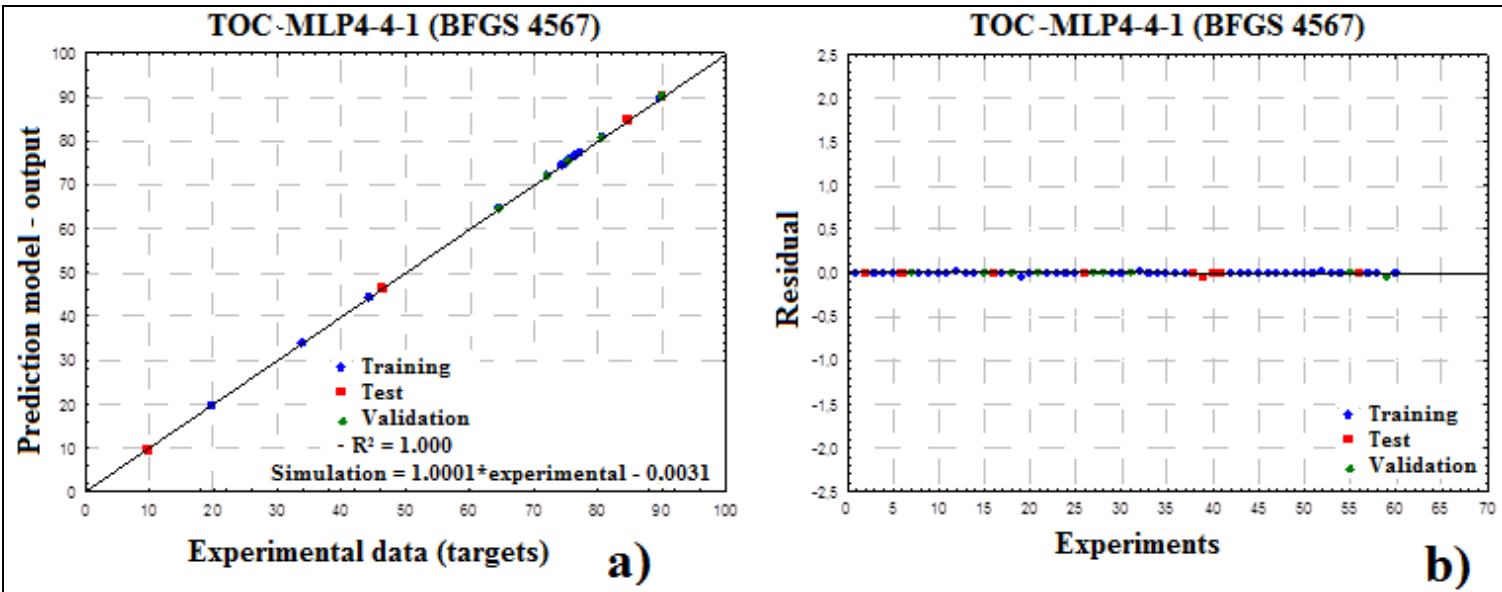

It can be stated, therefore, that the ANN model employed representes satisfactorily the behavior of the degradation process within the analyzed domain. This fact can be confirmed by the graph of residues from the conversion of the experimental TOC and simulated by MLP ANN (BFGS 4567) (Figure 10b). Through this Figure, the data of the residual analysis did not show dispersion tendencies around the x-axis. 


\subsection{Toxicity analysis}

To evaluate the toxic effects of the aqueous solution before and after the AOP treatment, toxicity tests were performed. The results of the bioassay averages, in triplicate, are show in Table 9. It is worth mentioning that the tests performed with the positive control did not present germination.

Table 9 - Average germinated seed for each species studied

\begin{tabular}{c|c|c|c|c}
\hline Sample & Americano hard & Cichorium endívia & Lactuta Sativa & Ocimum basilicum \\
\hline Water & $9.00 \pm 0.00$ & $8.33 \pm 0.58$ & $8.33 \pm 0.58$ & $8.66 \pm 0.58$ \\
\hline SBD & $5.33 \pm 0.58$ & $1.00 \pm 1.00$ & $5.66 \pm 0.58$ & $3.33 \pm 0.58$ \\
\hline SAD & $9.33 \pm 0.58$ & $9.33 \pm 0.58$ & $8.66 \pm 1.53$ & $9.66 \pm 0.58$ \\
\hline
\end{tabular}

$\left.{ }^{*}\right) \mathrm{SAD}=$ solution before degradation; SAD = solution after degradation

From Table 9 it can be inferred that number of seeds germinated when in contact with the solution before treatment were less when compared with the ones in contact with water, which indicates the presence of toxicity. A similar result was obtained by researches who evaluated the toxicity of pharmaceutical effluent for seeds, in which an inhibition of germination was verified (NAPOLEÃO et al, 2018).

The solution after the treatment behaved analogously to the negative control for the different concentrations evaluated, being possible to state that the compounds formed after the applied treatment do not present toxicity in relation to the species studied, with respect to germination. However, this study is not sufficient to assert that there is no toxicity of the analyzed compounds, and it is necessary to verify the root length (Table 10).

Table 10 - Average root growth for each species studied

\begin{tabular}{c|c|c|c|c}
\hline Sample & Americano hard & $\begin{array}{c}\text { Cichorium } \\
\text { endívia }\end{array}$ & Lactuta sativa & $\begin{array}{c}\text { Ocimum } \\
\text { basilicum }\end{array}$ \\
\hline Water & $7.20 \pm 0.75$ & $2.20 \pm 0.10$ & $5.83 \pm 0.60$ & $2.23 \pm 0.25$ \\
\hline SBD & $4.10 \pm 0.17$ & $0.53 \pm 0.31$ & $1.47 \pm 0.59$ & $0.53 \pm 0.45$ \\
\hline SAD & $7.37 \pm 0.60$ & $2.27 \pm 0.38$ & $5.23 \pm 0.64$ & $2.47 \pm 0.15$ \\
\hline
\end{tabular}

$\left.{ }^{*}\right) \mathrm{SBD}=$ solution before degradation; $\mathrm{SAD}=$ solution after degradation.

The results shown in Table 10 show that although some seeds may survive in potentially toxic medium (SBD), their development has suffered sublethal effects (inhibition of root development). Whereas after the treatment, no relative toxic effect was observed in the seeds. These data agree with those obtained by Napoleão et al (2014), who evaluated the toxicity of a pharmaceutical effluent submitted to the photo-Fenton process, against the Lactuta sativa seed and the Americano Hard grain. Finally, for a better understanding of the results, the germination index (GI) and the relative growth rate (RGR) were determined for the studied species, as can be observed in Table 11. 
Table 11 - RGR and GI values (\%) for each studied species

\begin{tabular}{c|c|c|c|c|c|c|c|c}
\hline \multirow{2}{*}{ Sample } & \multicolumn{3}{|c|}{ Americano hard } & \multicolumn{2}{c|}{ Cichorium endívia } & \multicolumn{2}{c}{ Lactuta sativa } & \multicolumn{2}{c}{ Ocimum basilicum } \\
\cline { 2 - 10 } & RGR & GI (\%) & RGR & GI (\%) & RGR & GI (\%) & RGR & GI (\%) \\
\hline Water & 1.00 & 100.00 & 1.00 & 100.00 & 1.00 & 100.00 & 1.00 & 100.00 \\
\hline SBD & 0.57 & 33.72 & 0.24 & 2.91 & 0.25 & 17.08 & 0.24 & 9.18 \\
\hline SAD & 1.02 & 106.07 & 1.03 & 115.40 & 0.90 & 93.27 & 1.10 & 123.20 \\
\hline
\end{tabular}

$\left({ }^{*}\right) \mathrm{SBD}=$ solution before degradation; SAD = solution after degradation

The analysis of Table 11 shows that there was interference in both the RGR and the GI of all studied species in the solution before treatment. On the other hand, the solution treated through the photo-Fenton process did not show a significant difference in relation to the indices evaluated, when compared to the behavior of the negative control. This indicates that the solution after treatment is less toxic than the initial sample containing the pharmaceuticals nimesulide and ibuprofen.

\section{CONCLUSION}

The present work allowed to verify that the photo-Fenton process was efficient in the treatment of the drugs nimesulide and ibuprofen, degrading $89.70 \%$ and $93.35 \%$ respectively. Besides reducing the concentration of chemical oxygen demand by $91.60 \%$ and mineralizing $90.04 \%$ of the organic matter by reducing the levels of total organic carbon. It was verified that the kinetic study presented a good linear fit, with $\mathrm{R}^{2}$ equal to 0.993 for the clustered kinetic model, as well as the artificial neural network MLP 4-4-1 BFGS 4567 can predict satisfactorily the data for the proposed treatment, having as response the TOC concentrations. Finally, the toxicity of the solution after the photo-Fenton process against the seeds of Lactuta Sativa (lettuce), Cichorium endívia (chicory), Ocimum basilicum (basil) and Americano Hard grain (wheat) were analyzed. Verifying that the seeds that received the solution before the AOP had a reduction of the germination, which was not observed when adding the solution after treatment. To complete the toxicity study, the root growth of the studied species was evaluated and no toxic effect was detected.

\section{ACKNOWLEDGEMENTS}

For Farmácia Escola of the Universidade Federal de Pernambuco, of the CAPES and for NUQAAPE/FACEPE.

\section{REFERENCES}

ALHARBI, S. K.; KANG, J.; NGHIEM, L. D.; van de MERWE, J. P.; LEUSCH, F. D. L.; PRICE, W. E. Photolysis and $\mathrm{UV} / \mathrm{H}_{2} \mathrm{O}_{2}$ of diclofenac, sulfamethozazole, carbamazepine and trimethoprim: Identification of their major degradation products by ESI-LC-MS and assessment of the toxicity of reaction mixtures. Process Safety and Environmental Protection, v. 112, p. 222-234, 2017.

APHA: AMERICAN PUBLIC HEALTH ASSOCIATION. Standard Methods for The Examination of Water and Wastewater. 22 ed. Washington: APHA, 2012. 
ARAÚJO, K. S.; ANTONEL, R.; GAYDECZKA, B.; GRANATO, A. C.; MALPASS, G. R. P. Processos oxidativos avançados: uma revisão de fundamentos e aplicações no tratamento de águas residuais urbanas e efluentes industriais. Revista Ambiente \& Água, v. 11, n. 2, p. 387-401, 2016.

BIALK-BIELINSKA, A.; KUMIRSKA, J.; BORECKA, M.; CABAN, M.; PASZKIEWICZ, M.; PAZDRO, K.; STEPNOWSKI, P. Selected analytical challenges in the determination of pharmaceuticals in drinking/marine waters and soil/sediment samples. Journal of Pharmaceutical and Biomedical Analysis, v. 121, p. 271-296, 2016.

BORGES, E. M.; GORAIEB, K.; COLLINS, C. H. O desafio de analisar solutos básicos por cromatografia líquida em modo reverso: algumas alternativas para melhorar as separações. Química Nova, 35, n. 5, p. 993-1003, 2012.

BRASIL. AGÊNCIA NACIONAL DE VIGILÂNCIA SANITÁRIA (ANVISA). Resolução no 899, de 29 de maio de 2003. Guia para validação de métodos analíticos e bioanalíticos. Diário Oficial da União, Brasília, 02 de junho de 2003.

BRASIL. CONSELHO NACIONAL DO MEIO AMBIENTE (CONAMA). Resolução no 430, de 13 de maio de 2011. Dispõe sobre as condições e padrões de lançamento de efluentes. Diário Oficial da República Federativa do Brasil, Brasília, DF, v. 13, 2011.

BRITO, N. N. D.; SILVA, V. B. M. Processos oxidativos avançados e sua aplicação ambiental. Revista Eletrônica de Engenharia Civil, v. 1, n. 3, p. 36-47, 2012.

CANDIDO, J. P. Remoção de ibuprofeno por fotocatálise heterogênea e avaliação ecotoxicológica de possíveis subprodutos. 2016. 72 f. Dissertação (Mestrado em Meio Ambiente e Recursos Hídricos) Universidade Federal de Itajubá, Itajubá, MG, 2016.

CARLSON, J. C.; STEFAN, M. I.; PARNIS, M. P.; METCALFE, C. D. Direct UV photolysis of selected pharmaceuticals, personal care products and endocrine disruptors in aqueous solution. Water Research, v. 84, p. 350-361, 2015.

CHRISTOU, A.; KARAOLIA, P.; EVROULA, H.; MICHAEL, C.; FATTA-KASSINOS, D. Long-term wastewater irrigation of vegetables in real agricultural systems: Concentration of pharmaceuticals in soil, uptake and bioaccumulation in tomato fruits and human health risk assessment. Water Research, v. 109, p. 24-34, 2017.

COSTA, F. M.; CAMPOS, J. C.; FONSECA, F. V.; BILA, D. M. Tratamento de lixiviados de aterros de resíduos sólidos utilizando processos Fenton e foto-Fenton Solar. Revista Ambiente \& Água, v. 10, n. 1, p. 107-116, 2014.

EBELE, A. J.; ABDALLAH, M. A-E.; HARRAD, S. Pharmaceuticals and personal care products (PPCPs) in the freshwater aquatic environment. Emerging Contaminants, v. 3, n. 1, p. 1-16, 2017. 
ERAGA, S. O.; ARHEWOH, M. I.; CHIBUOGWU, R. N.; IWUAGWU, R. N. A comparative UV-HPLC analysis of ten brands of ibuprofen tablets. Asian Pacific Journal of Tropical Biomedicine, v. 5, p. 880-884, 2015.

FUNAI, D. H.; DIDIER, F.; GIMÉNEZ, J.; ESPLUGAS, S.; MARCO, P.; JUNIOR, A. M. Photo-Fenton treatment of valproate under UVC, UVA and simulated solar radiation. Journal of Hazardous Materials, v. 323, p. 537-549, 2017.

GIRI, A. S.; GOLDER, A. K.; Decomposition of drug mixture in Fenton and photo-Fenton processes: Comparison to singly treatment, evolution of inorganic ions and toxicity assay. Chemosphere, v. 127, p. 254-261, 2015.

GRUBBS, F. E.; BECK, G. Extension of sample sizes and percentage points for significance tests of outlying observations. Technometrics, v. 14, n. 4, p. 847-854, 1972.

INSTITUTO NACIONAL DE METROLOGIA, NORMALIZAÇÃO E QUALIDADE INDUSTRIAL (INMETRO). DOQ-CGCRE-008: Orientações sobre Validação de Métodos Analíticos. Rev. 04, 2011. 20 p.

JALIL, A.; ATA, E.; MILAD, A.; VAHID, R. Statistical process control using optimized neural networks: A case study. ISA Transactions, v. 53, p. 1489-1499, 2014.

LIMA, D. R. S.; ALMEIDA, I. L. A.; PAULA, V. I. Degradação do corante Azul Reativo 5G elo processo oxidativo avançado UV/H2 $\mathrm{O}_{2}$. E-Xacta, v. 9, n. 2, p. 101-109, 2016.

LUAN, M.; JING, G.; PIÃO, Y.; LIU, D.; JIN, L. Treatment of refractory organic pollutants in industrial wastewater by wet air oxidation. Arabian Journal of Chemistry, v. 10, p. 769-776, 2017.

MALTESE, A.; MAUGERI, F.; BUCOLO, C. Rapid determination of nimesulide in rabbit aqueous humor by liquid chromatography. Journal of Chromatography B, v. 804, p. 441-443, 2004.

MORAES, S.C.G.; ZAIDAN, L.E.M.C.; NAPOLEÃO, D. C.; CARVALHO, F. O.; MONTENEGRO, M. C. B.; SILVA, V. L. Implementing artificial neural networks modelling after the treatment of oil refinery effluents using advanced oxidation processes. Brazilian Journal of Petroleum and Gas, v. 10, n. 1, p. 23-32, 2016.

NAPOLEÃO, D. C.; ZAIDAN, L. E. M. C.; DIAZ, J. M. R.; SANTANA, R. M. R.; MONTENEGRO, M. C. B.; ARAUJO, A. N.; BENACHOUR, M.; SILVA, V. L. Use of the photo-Fenton process to discover the degradation of drugs present in water from the Wastewater Treatment Plants of the pharmaceutical industry. Afinidad, v. 75, p. 19-27, 2018.

NAPOLEÃO, D. C.; ZAIDAN, L. E. M. C.; SALGADO, J. B. A.; SALES, R. V.; SILVA, V. L. Degradação do contaminante emergente paracetamol empregando processos oxidativos avançados. Electronic Journal of Management, Education and Environmental Technology (REGET), v. 19, n. 3, p. 725-734, 2015. 
NAPOLEÃO, D. C.; PINHEIRO, R. B.; ZAIDAN, L. E. M. C.; SALES, R. V. L.; BENACHOUR, M.; SILVA, V. L. Avaliação de toxicidade após submissão de efluente oriundo de ETE ao processo fotoFenton like frente à semente de Lactuta sativa e ao grão Americano hard. In: Congresso Brasileiro de Engenharia Química, Out 2014. Florianópolis.

NAPOLEÃO, D. C.; BRANDÃO, Y. B.; BENACHOUR, M.; SILVA, V. L. Estudo do processo FotoFenton para tratamento de fármacos: otimização e modelagem cinética. Scientia Plena, v. 9, n. 9, p. 19, 2013.

NAVARRO, P.; GABALDÓN, J. A.; GÓMEZ-LÓPEZ, V. M. Degradation of an azo dye by a fast and innovative pulsed light $/ \mathrm{H}_{2} \mathrm{O}_{2}$ advanced oxidation process. Dyes and Pigments, v. 136, n. 1, p. 887-892, 2017.

PEAKE, B. M.; BRAUND, R.; TONG, A. Y. C.; TREMBLAY, L. A. The Life-Cycle of Pharmaceuticals in the Environment. Cambridge: ELSEVIER, UK, 2016.

PERLATTI, B.; SILVA, M. F. G. F.; FERNANDES, J. B.; FORIM, M.R. Validation and application of HPLC-ESI-MS/MS method for the quantification of RBBR decolorization, a model for highly toxic molecules, using several fungi strains. Bioresource Technology, v. 124, n. 1, p. 37-44, 2012.

PEREIRA, A. V.; GARABELI, A. A.; SCHUNEMANN, G. D.; BORCK, P. C. Determinação da constante de dissociação (Ka) do captopril e da nimesulida - experimentos de química analítica para o curso de farmácia. Química Nova, v. 34, n. 9, p. 1656-1660, 2011.

PINTO, L. H.; CARDOZO, G.; SOARES, J. C.; ERZINGER, G. S. Toxicidade ambiental de efluentes advindo de diferentes laboratórios de uma farmácia magistral. Revista Ambiente \& Água, v. 11, n. 4, p. 819-832, 2016.

RAJABI, M.; MIRZA, B.; MAHANPOOR, K.; MIRJALILI, M.; NAJAFI, F.; MORADI, O.; SADEGH, H., SHAHRYARI-GHOSHEKANDI, R.; ASIF, M.; TYAGI, I.; AGARWAL, S.; GUPTA, V. K. Adsorption of malachite green from aqueous solution by carboxylate group functionalized multiwalled carbon nanotubes: Determination of equilibrium and kinetics parameters. Journal of Industrial and Engineering Chemistry, v. 34, p. 130-138, 2016.

ROCHA, O. R. S.; DUARTE, M. M. M. B.; DANTAS, R. F.; DUARTE, M. M. L.; SILVA, V. L. Oil sludge treatment by solar Tioz-photocatalysis to remove polycyclic aromatic hydrocarbons (PAH). Brazilian Journal of Petroleum and Gas, v. 8, n. 3, p. 89-96, 2014.

ROMERO, V.; GONZÁLEZ, O.; BAYARRI, B.; MARCO, P.; GIMÉNEZ, J.; ESPLUGAS, S. Degradation of Metoprolol by photo-Fenton: Comparison of different photoreactors performance. Chemical Engineering Journal, v. 283, p. 639-648, 2016. 
SANTANA, R. M. R.; NASCIMENTO, G. E.; NAPOLEÃO, D. C.; DUARTE, M. M. M. B. Degradation and kinetic study of Reactive blue BF-5G and Remazol red RB 133\% dyes using Fenton and photoFenton process. Electronic Journal of Management, Education and Environmental Technology (REGET), v. 31, n. 2, p. 104-118, 2017.

SANTOS-JUANES, L.; SÁNCHEZ, G. J. L.; LÓPEZ, C. J. L.; OLLER, I.; MALATO, I.; PÉREZ, S. J. A. Dissolved oxygen concentration: A key parameter in monitoring the photo-Fenton process. Applied Catalysis B: Environmental, v. 104, n. 3, p. 316-323, 2011.

SILVA, J. M.; MENDONÇA, P. P.; PARTATA, A. K. Anti-inflamatórios não-esteróides e suas propriedades gerais. Revista Científica do ITPAC, v. 7, n. 4, p. 1-15, 2014.

SKORONSKI, E.; FERRARI, A.; FERNANDES, M.; ELY, C.; JOÃO, J. J. Desempenho de um reator Fenton em escala industrial aplicado à remoção de fenóis em uma planta de recuperação de resíduos da indústria de papel e cellulose. Revista Ambiente \& Água, v. 10, n. 4, p. 863-874, 2015.

SOUZA, R. R. Desenvolvimento e validação de metodologia analítica para determinação de desregulação endócrina resultante de atividades antrópicas nas águas do Rio Paraíba do Sul. 2011. 205 f. Dissertação (Mestrado em Tecnologia Nuclear - Materiais) - Universidade de São Paulo, São Paulo, SP, 2011.

STOYANOVA, K.; VINAROV, Z.; TCHOLAKOVA, S. Improving ibuprofen solubility by surfactantfacilitated self-assembly into mixed micelles. Journal of Drug Delivery Science and Technology, v. 36, n. 1, p. 208-215, 2016.

VALCÁRCEL, Y.; GONZÁLEZ, A. S.; RODRIGUEZ-GIL, J. L.; GIL, A.; CATALÁ, M. Detection of pharmaceutically active compounds in the rivers and tap water of the Madrid Region (Spain) and potential ecotoxicological risk. Chemosphere, v. 84, n. 1, p. 1336-1348, 2011.

YOUNG, B. J.; RIERA, N. I.; BEILY, M. E.; BRES, P. A.; CRESPO, D. C.; RONCO, A. E. Toxicity of the effluent from an anaerobic bioreactor treating cereal residues on Lactuca sativa. Ecotoxicology and Environmental Safety, v. 76, n. 2, p. 182-186, 2012.

ZAIDAN, L. E. M. C.; SILVA, A. M. R. B.; SALES, R. V.; SALGADO, J. B. A.; MORAES, S. C. G.; SOUZA, D. P.; GALVÃO, C. C.; RODRIGUEZ-DIAZ, J. M.; NAPOLEÃO, D. C.; BENACHOUR, B., SILVA, V. L. Optimization of phenol degradation and its derivatives using photo-Fenton and application industrial. Chemical and Process Engineering Research, v. 42, n. 1, p. 44-52, 2016.

ZANCHETA, P. G.; PENA, A.; GONÇALVES, R. F. Desenvolvimento e validação de método para quantificação simultânea de ofloxacina, norfloxacina e ciprofloxacina em urina humana. Engenharia Sanitária e Ambiental, v. 20, n. 2, p. 307-314, 2016.

ZHANG, Q.; CHUANG, K. T. Lumped kinetic model for catalytic wet oxidation of organic compounds in industrial wastewater. AIChE Journal, v. 45, n. 1, p. 145-150, 1999. 